특집논문-10-15-6-01

$$
\begin{gathered}
\text { 진동촉각 햅틱 마우스 기반 버블포핑 증강현실 시스템 } \\
\text { 정 다 운 }{ }^{a)} \text { 이 우 근a), 장 성 은 }{ }^{a)} \text { 김 만 배 }{ }^{a}
\end{gathered}
$$

\title{
Bubble Popping Augmented Reality System Using a Vibro-Tactile Haptic Mouse
}

\author{
Da Un Jung ${ }^{\text {a)}}$, Woo Keun Lee ${ }^{\text {a)}}$, Seong Eun Jang ${ }^{\text {a)}}$, Man Bae Kim ${ }^{\text {a) }}$ \\ 요 약
}

본 논문에서는 증강현실 응용으로 진동촉각 햅틱 마우스를 이용하여 버블 포핑을 구현하는 버블포핑 증강현실 시스템을 제안한다. 이 시스템에서는 가상 그래픽 버블이 3차원 공간에서 랜덤하게 떠다닌다. 사용자의 진동촉각마우스가 버블과 접촉하면 버블이 터지는 포핑이 발생한다. 또한 포핑 효과와 더불어, 마우스가 진동을 함으로써 마우스를 잡고 있는 사용자의 손에 보다 실감나는 버블포핑을 전달한다. 제안 시스템은 진동촉각마우스, 비디오 입력용 웹캠, 마커 패턴 영상, 그래픽 구 버블 객체, 그래픽 마우스 등으로 구성된다. 버블과의 충돌이 발생하게 되면, 마우스 진동과 버블 포핑의 두가지 효과를 동시에 제공한다. 버블포핑 이벤트로 페이드 아웃 및 발산 페이드 아웃 기법을 제안한다. 따라서 시각 및 촉각 버블 포핑은 단일 효과보다 실감있는 증강현실을 전달한다.

\begin{abstract}
As one of applications in augmented realities, this paper presents a bubble popping system utilizing a haptic vibro-tactile mouse. In this system, virtual bubbles randomly float in the 3D space. By using the vibro-tactile mouse grabbed by a user, the bubbles are popped when they are touched by the mouse in the 3D space. Then a bubble popping effect with addition mouse vibration is delivered to the user's hand through the mouse. The proposed system is developed on ARToolkit environment. Therefore, basic components such as a camera and a marker pattern are required. The systems is composed of a vibro-haptic mouse, a webcam, a marker pattern, a graphic bubble object, and graphic mouse. Mouse vibration as well as bubble fade-out effect is delivered. Therefore, the combination of visual and tactile bubble popping effects outperforms the usage of a single effect in the experience of augmented reality.
\end{abstract}

Keywords : AR(augmented reality), vibro-haptic mouse, haptic, bubble popping

a) 강원대학교 컴퓨터정보통신공학과

Kangwon National Univ., Dept. of Computer \& Communications

\# 교신저자 : 김만배 (manbae@kangwon.ac.kr)

※ 본 연구는 교육과학기술부와 한국산업기술진흥원의 지역혁신인력양 성사업의 연구결과 및 지식경제부 및 정보통신산업진흥원의 대학 IT 연구센터 지원사업의 연구결과로 수행되었음 (NIPA-2010-(C10901011-0003)).

· 접수일(2010년8월11일),수정일(1차:2010년10월25일,2차:11월8일),게재확정 일(2010년11월9일)

\section{I. 서 론}

최근 가상 및 증강현실 기술의 발전으로 사용자에게 몰 입감 있는 콘텐츠를 제공하는 여러 시스템들이 제안되고 있다 ${ }^{[1-6]}$. 증강현실(augmented reality)은 실사영상과 $\mathrm{CG}$ 의 합성을 이용하여 엔터테인먼트, 게임, 교육 분야의 다양한 분야에서 구현되고 있는데, 본 논문에서는 햅틱 장치인 진
\end{abstract}


동촉각마우스(vibro-tactile mouse)을 기반으로 하는 버블 포핑(bubble popping) 시스템을 제안한다. 제안 시스템은 본 실험실에서 제작한 진동촉각마우스, 비디오 입력용 웹 캠, 마커 패턴, 및 비디오와 $\mathrm{CG}$ 객체의 합성을 담당하는 컴퓨터로 구성되고, 모니터에서는 그래픽 버블 객체, 그래 픽 마우스를 디스플레이한다.

증강현실 시스템에 햅틱 기기를 접목하는 것은 현재 활 발한 연구가 진행중인 분야이다 ${ }^{[7-10]}$. 다양한 분야에서 햅틱 기기를 이용한 증강현실 시스템의 가능성을 꾸준히 검증해 왔다. 햅틱 기기는 일반적으로 팬텀, 글로브 등이 사용되어 왔다. Sziebig 등은 글러브 형의 진동촉각 기기를 이용하여 가상현실에 응용을 하였다 ${ }^{[7]}$. 또한 Piekarski 등은 기존의 글로브에서 소비전력 감소 및 무선 통신이 가능한 햅틱 글 로브를 제안하였다 ${ }^{[8]}$. Herbst 등은 데이터 글러브를 이용하 여 사용자가 느끼는 진동촉각의 성능을 조사하였다 ${ }^{[9]}$. Vallino 등은 팬텀 햅틱 기기를 이용하여 가상 객체의 이동, 회전 등이 변환을 수행하였다 ${ }^{[10]}$.

기존 햅틱 기기와 달리, 실험실에서 자체 개발한 진동촉 각마우스는 사용자가 쉽게 손으로 잡을 수 있는 특징이 있 으며 무선통신의 기능을 가지고 있다. 무선통신을 사용하 기 때문에 센서와 컴퓨터를 연결하는 선이 불필요하여 사 용하기가 간편하다. 진동촉각마우스의 이동 및 회전에 따 라 그래픽 마우스가 모니터의 3 차원 공간에서 이동하면서 그래픽 버블과 충돌하면, 충돌 시 발생하는 버블 포핑의 이 벤트로 페이드 아웃(fadeout)과 발산 페이드 아웃(diverging fade-out)을 제안한다. 제안 시스템은 ARToolkit을 기반으 로 제작되었으며 ${ }^{[1]}$, 시각적인 마커 기반 시스템으로 버블 포핑 이벤트와 사용자에게 전달되는 진동촉각을 통해 증강 현실을 전달할 수 있다.

본 논문의 구성은 다음과 같다. 제안 시스템 구조는 ㅍㅈㅏㅏㅇ 에서 소개된다. II장에서는 진동촉각마우스의 기능을 자세 히 설명한다. 버블포핑 이벤트 방법을 IV장에서 제안하고, 실험결과는 $\mathrm{V}$ 장에서 설명한다. 마지막으로 $\mathrm{VI}$ 장에서 결론 및 향후 연구를 정리한다.

\section{II. 제안하는 버블포핑 시스템}

제안하는 증강현실 시스템은 기본적으로 ARToolKit 소 프트웨어를 기반으로 제작된다 ${ }^{[11]}$. 먼저 USB 캠으로부터 비디오 프레임을 입력 받고 마커패턴의 위치를 설정한다. 버블을 그래픽으로 구현하기 위하여 구(sphere)로 모델링 하였으며, 여러 개의 버블을 제작하였다. 3 차원 공간상의 그래픽 마우스는 진동촉각마우스를 사용하여 제어하게 된 다. 흔히 사용하는 키보드나 일반 마우스가 아닌 햅틱 장치 를 사용하기 때문에, 보다 몰입감 있고 실감나는 증감을 전 달한다. 이 마우스에는 진동 센서가 있어서, 마우스를 잡고 있는 손에 진동을 전달한다. 그래픽 마우스가 버블과 충돌 하면 페이드 아웃과 발산 페이드 아웃 등의 버블포핑 이벤 트가 발생하여 시각적 및 촉감으로 버플이 터지는 포핑을 느끼게 된다. 또한 사용자의 시각적 이해를 돕기 위해 충돌 되는 버블의 색을 변경한다. 진동촉각마우스를 통해 포스 피드백 진동감을 주어 사용자가 보다 실감나는 증감을 느 끼게 하는 시스템이다. 그림 1 은 본 논문에서 제안하는 증 강현실 시스템의 전체 블록도를 보여준다.

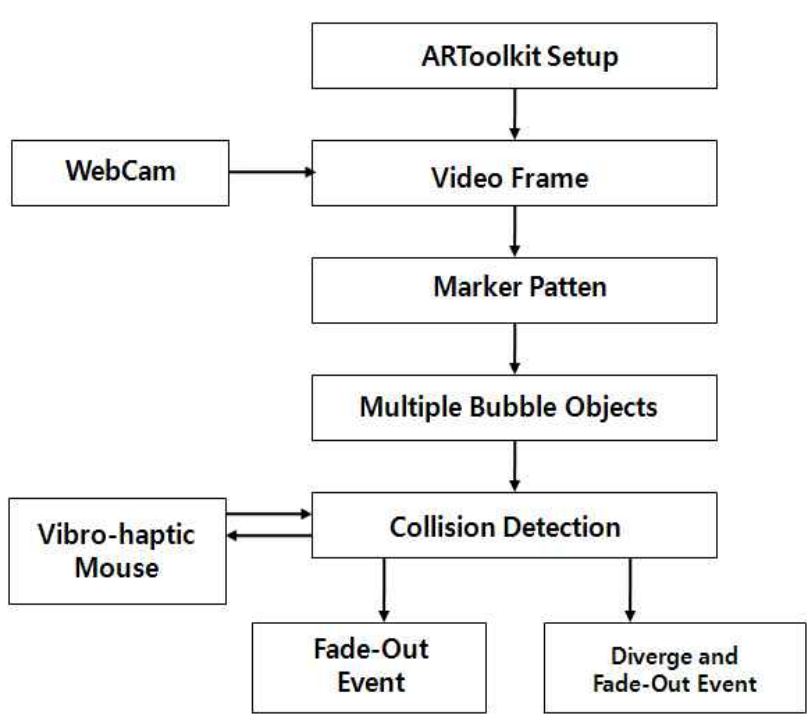

그림 1. 버블포핑 증강현실 시스템 블록도

Fig. 1 Block diagram of bubble popping augmented reality system 
이 시스템은 3 차원공간에서 그래픽 버블의 위치를 설정 하기 위해 진동촉각마우스의 트랙킹이 필요하다 ${ }^{[12]}$. 진동촉 각마우스의 위치는 그래픽 마우스의 위치와 일치되어야 하 는데, 사용자가 마우스를 움직일 때에 그래픽 마우스도 이 동 및 회전을 하게 된다. 그래픽 마우스가 버블 마우스와 접촉(충돌)하게 되면, 그래픽 버블은 포핑하고, 촉각 진동 (tactile vibration)이 사용자에게 전달된다. 그래픽 객체들은 OpenGL 라이브러리를 사용하여 구형으로 모델링하였다. 진동촉각마우스는 마우스 진동 및 무선통신 등의 기본 기 능을 장착하고 있고, 진동 시간은 2 3초이다.

시스템의 구조는 그림 2에서 보여진다. 진동촉각마우스 와 컴퓨터는 시리얼 포트로 송수신이 가능하다. 진동촉각 마우스는 8 바이트의 마우스 정보 데이터를 컴퓨터로 전송 한다. 컴퓨터에서 충돌이 발생하면 진동촉각마우스의 $(\mathrm{X}$, $\mathrm{Y}$ ) 좌표 및 12 바이트의 진동 데이터가가 마우스로 전달된 다. 이에 따라 진동이 발생한다.

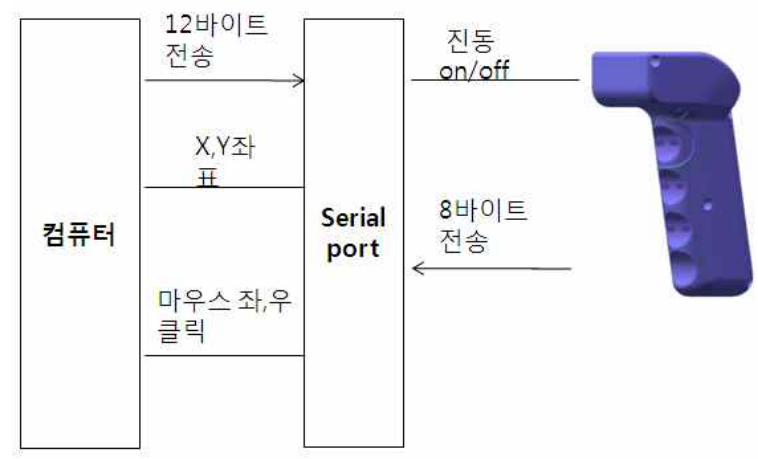

그림 2. 버블포핑 시스템 구조

Fig. 2 The system configuration of bubble popping system

\section{III. 진동촉각마우스}

그림 3의 진동촉각마우스는 블루투스 무선통신을 사용 하여 시스템과 마우스의 통신이 이루어진다. 진동촉각마우 스는 센서를 이용하여 공간상에서 마우스의 위치 좌표를 생성하게 되고 컴퓨터는 이 좌표를 수신받아 그래픽 마우 스의 위치를 결정하게 된다.

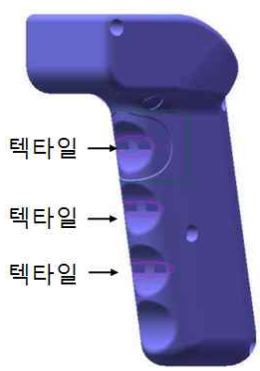

그림 3. 진동촉각마우스

Fig. 3 Vibro-tactile mouse

컴퓨터와 마우스는 통신시 서로 다른 크기의 바이트 데 이터를 사용한다. 컴퓨터는 마우스로부터 8 바이트 데이 터를 수신하여, 이 데이터로부터 $(\mathrm{X}, \mathrm{Y})$ 좌표, 마우스 클릭 이벤트를 알아낸다. 또한 마우스는 12 바이트의 데이터를 시스템으로부터 수신하여 부착된 텍타일에 진동을 on/off 한다.

마우스로부터 수신하는 8 바이트에서 0,1 번째 바이트는 check sum 데이터, 2 5번째 바이트는 마우스의 (X, Y) 좌 표 데이터, 6 번째 byte는 마우스의 좌-우 버튼 데이터를 가지고 있다. 7번째 바이트는 사용하지 않는다. 표 1은 마우 스정보 데이터를 보여준다.

표 1. 8 바이트의 마우스 정보 데이터 Table 1. 8-byte data of mouse

\begin{tabular}{|c|c|c|c|c|c|c|c|}
\hline 7 & 6 & 5 & 4 & 3 & 2 & 1 & 0 \\
\hline$x$ & $\begin{array}{c}\text { Right/left } \\
\text { button }\end{array}$ & $\begin{array}{c}\text { Y axis } \\
\text { low } \\
8 \text { bit }\end{array}$ & $\begin{array}{c}\text { Y axis } \\
\text { high } \\
8 \text { bit }\end{array}$ & $\begin{array}{c}\text { X axis } \\
\text { low } \\
8 \text { bit }\end{array}$ & $\begin{array}{c}\text { X axis } \\
\text { high } \\
8 \text { bit }\end{array}$ & $\begin{array}{c}\text { Check } \\
\text { sum }\end{array}$ & $\begin{array}{c}\text { Check } \\
\text { sum }\end{array}$ \\
\hline
\end{tabular}

마우스가 컴퓨터로부터 수신하는 12 바이트의 진동 데이 터에서 0,1 번째 바이트를 check sum 으로 사용하고 6 11 번째까지의 6 개의 바이트는 마우스에 부착된 각 텍타일에 사용될 데이터를 저장한다. 표 2 는 12 바이트의 진동 데이 터를 보여준다.

표 2. 12 바이트의 진동 데이터. $\mathrm{T}=$ Tactile, $\mathrm{CS}=$ checksum, $\mathrm{N}=$ unused Table 2. 12-byte vibration data. $\mathrm{T}=$ Tactile, $\mathrm{CS}=$ checksum, $\mathrm{N}=$ unused \begin{tabular}{|c|c|c|c|c|c|c|c|c|c|c|c|}
\hline 11 & 10 & 9 & 8 & 7 & 6 & 5 & 4 & 3 & 2 & 1 & 0 \\
\hline $\mathrm{T}$ & $\mathrm{T}$ & $\mathrm{T}$ & $\mathrm{T}$ & $\mathrm{T}$ & $\mathrm{T}$ & $\mathrm{N}$ & $\mathrm{N}$ & On/Off & $\mathrm{N}$ & $\mathrm{CS}$ & $\mathrm{CS}$ \\
\hline
\end{tabular} 
그래픽 마우스와 그래픽 버블이 충돌하게 되면 컴퓨터는 진동촉각마우스에게 피드백을 전송하고 마우스에 부착된 6 개의 텍타일을 통해 사용자가 진동을 느끼게 된다 (그림 3).

\section{IV. 충돌 검출 및 버블 포핑 이벤트}

충돌검출(collision detection)은 증강현실 구현에 중요한 기술이다 ${ }^{[13]}$. 모델 데이터의 복잡도에 따라 처리시간이 결 정되는데, 실시간 처리에서는 복잡도가 낮은 알고리즘과 모델 데이터의 양을 줄이는 것이 필요하다. 제안 시스템에 서의 사용하는 버블은 간단하게 구형으로 모델링할 수 있 고, 진동촉각마우스도 유사하게 구형으로 모델링함으로써, 충돌검출 알고리즘의 단순화가 가능하다.

3 차원 공간에서 두 구의 충돌 검출은 두 구의 중심점 간 의 거리를 통하여 구할 수 있다. 구의 경우 어느 방향에서 충돌하여도 거리가 반드시 두 구의 반지름의 합이다. 그림 4 에서 보는 것처럼 버블 구의 중심이 $\left(\mathrm{x}_{0}, \mathrm{y}_{0}, \mathrm{z}_{0}\right)$ 이고 반경 $\mathrm{R}_{0}$ 이고, 마우스 구의 중점이 $\left(\mathrm{x}_{1}, \mathrm{y}_{1}, \mathrm{z}_{1}\right)$ 이고 $\mathrm{R}_{1}$ 인 경우, 두 중점사이의 거리 $\mathrm{d}$ 는 다음 식 (1)과 같이 계산된다.

$$
d=\sqrt{\left(x_{1}-x_{0}\right)^{2}+\left(y_{1}-y_{0}\right)^{2}+\left(z_{1}-z_{0}\right)^{2}}
$$

따라서, $\mathrm{d} \leq\left(\mathrm{R}_{0}+\mathrm{R}_{1}\right)$ 조건을 만족하면 충돌이 발생한다.

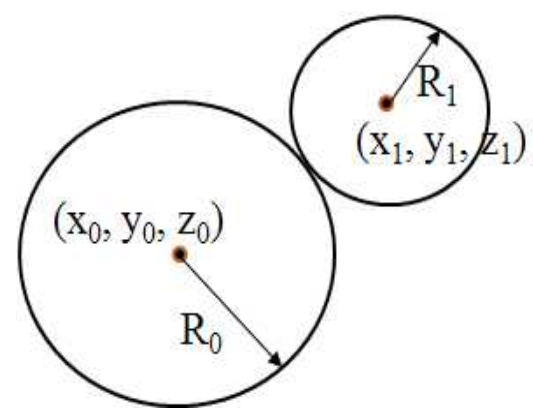

그림 4. 두 구의 충돌 검출 방법

Fig. 4 Collision detection method of two sphere objects

두 구가 충돌하면, 객체가 튕겨져 나가는 포핑이 발생한
다. 시각적인 효과를 보여주기 위해서 구가 점진적으로 사 라지는 페이드 아웃(fadeout)과 발산하면서 사라지는 발산 페이드 아웃(diverging fadeout)의 두가지 포핑 이벤트를 사 용한다. 포핑 이벤트의 2가지 주요 기술은 포핑하면서 이동 하는 속도 및 풍선이 터지는 효과를 얻기 위한 버블의 점진 적 소멸이다. 먼저 이동하는 속도는 다음과 같이 계산된다. 가감속 알고리즘을 적용하여 튕겨져 나가는 객체는 속도가 점차 줄어들게 된다. 프레임율이 $\mathrm{f}_{\mathrm{r}} \mathrm{fps}$ 이면, 각 프레임당 이 동거리 $\mathrm{Dn}$ 은 다음과 같다.

$$
D_{n}=\sin \left(\left(\frac{90}{f_{r}} \cdot n\right) \pi\right) \cdot D \quad 0<n \leq f_{r}
$$

실험에서는 $f_{r}$ 값으로 15 을 사용하였다.

버블 페이드 아웃은 시간축으로 삼각형 메시가 랜덤하게 사라진다. 버블 삼각 메쉬의 전체 개수를 $\mathrm{N}, \mathrm{F}$ 는 프레임 번 호 $(\mathrm{F} \geq 1)$, 사라지는 비율은 $\mathrm{r}$ 이면, 사라지는 삼각형의 개수 $\mathrm{N}$ 은 식 (3)에서 구해진다.

$$
N^{\prime}=r \cdot F \cdot N
$$

전체 삼각형 개수에서 $\mathrm{N}^{\prime}$ 만큼 랜덤으로 선택하여 삭제 한다.

2번째 버블 이벤트인 발산 페이드 아웃은 이동없이 삼각 형의 개수를 줄여가는 페이드 아웃과는 달리, 삼각형이 발 산하면서 사라지는 것이다. 발산 페이드 아웃 알고리즘은 다음과 같다:

Step 1: 각 삼각형의 법선벡터(normal vector)를 구함 Step 2: 법선벡터 방향으로 삼각형을 이동함

Step 3: 이동을 하면서, 삼각형의 크기를 스케일링함

Step 4: 모든 삼각형이 사라지면 중단함.

각 삼각형의 중점을 구하고 중점과 구의 원점사이의 법 선벡터를 구한다. 프레임마다 이 법선벡터 방향으로 이동 시키며, 또한 스케일링때문에 삼각형의 크기는 점차 작아 지다가 사라진다. 삼각형 메쉬로 이루어진 구가 그림 4 와 
같을 때 삼각형 $\mathrm{ABC}$ 의 중점 $\mathrm{G}=(\mathrm{Px}, \mathrm{Py}, \mathrm{Pz})$ 는 식 (4)에서 계산된다.

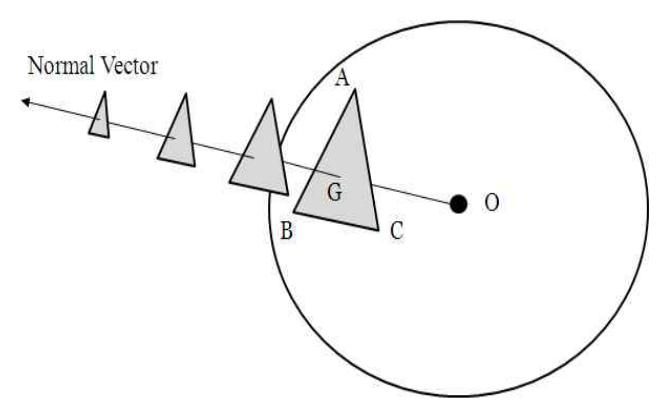

그림 4. 발산 페이드 아웃이벤트의 그래픽 표현

Fig. 4 Graphical illustration of diverging fade-out

$$
\begin{aligned}
& P_{x}=\left(A_{x}+B_{x}+C_{x}\right) / 3 \\
& P_{y}=\left(A_{y}+B_{y}+C_{y}\right) / 3 \\
& P_{z}=\left(A_{z}+B_{z}+C_{z}\right) / 3
\end{aligned}
$$

구의 중점 $\mathrm{O}=\left(R_{x}, R_{y}, R_{z}\right)$ 와 $G=\left(P_{x}, P_{y}, P_{z}\right)$ 의 단위벡 터는 식 (5)에서 계산된다.

$$
\overrightarrow{O G}=\frac{1}{\sqrt{\Delta \mathrm{X}^{2}+\Delta \mathrm{Y}^{2}+\Delta \mathrm{Z}^{2}}}(\Delta \mathrm{X}, \Delta \mathrm{Y}, \Delta \mathrm{Z})
$$

여기서 $\Delta X=P_{x}-R_{x}, \Delta Y=P_{y}-R_{y}, \Delta Z=P_{z}-R_{z}$ 이다. 삼각형 $\mathrm{ABC}$ 는 벡터 $\mathrm{OG}$ 방향으로 이동한다. $\mathrm{n}$ 번째 프레 임에서의 이동거리 $\mathrm{d}_{\mathrm{n}}$ 는 식 (6)과 같다.

$$
d_{n}=k \cdot\left(\sum_{i=0}^{n-1} d_{i}\right) \cdot \overrightarrow{O G}
$$

여기서 $d_{0}=1$ 이다. 삼각형이 법선벡터 방향으로 이동 하는 속도가 크기가 작아지는 속도보다 항상 커야 하는데, 상수 $\mathrm{k}$ 로 조절할 수 있다.

\section{V. 실험 결과}

제안하는 버블포핑 시스템은 웹캠, 마커 패턴, 진동촉각 마우스 및 모니터로 구성되어 있다. 사용자는 진동촉각마우 스를 손으로 잡는다. 그림 5는 OpenGL로 버블을 와이어 프 레임 구로 모델링한 결과를 보여준다 ${ }^{[14]}$. 웹캠에서 얻어지는 비디오와 마커패턴으로부터 카메라와 마커의 상대적인 이 동 및 회전 변환행렬은 ARTookit 라이브러리에서 제공해준 다. 소프트웨어는 OpenGL, Visual C++, 및 ARToolkit 라 이브러리 기반으로 제작되었다.

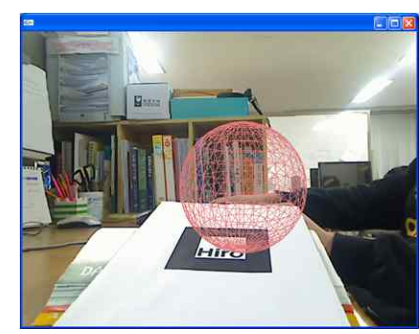

그림 5. 버블 객체의 구 모델링

Fig. 5 Sphere wireframe modeling of a bubble object

발산 페이드 아웃 이벤트의 예는 그림 6 에서 보여진다. 이 이벤트는 버블이 구의 중심으로부터 멀어져가면서 터지 게 되며, 동시에 삼각형 메쉬의 개수들이 점진적으로 줄어 들게 된다.

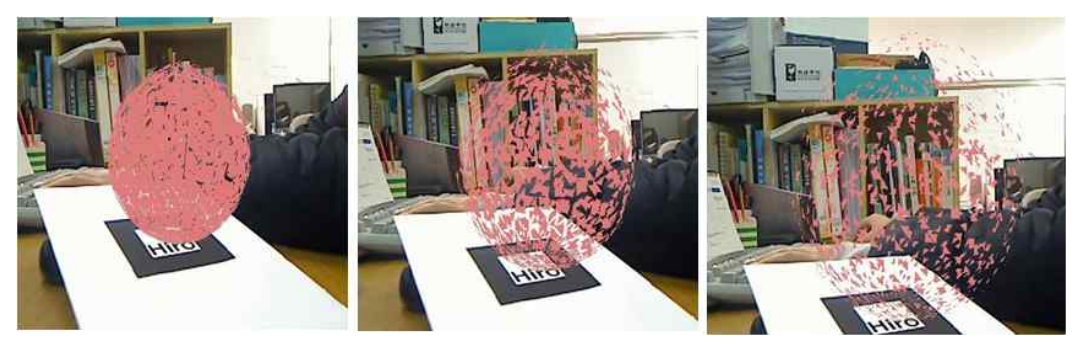

그림 6. 발산 페이드 아웃 버블 포핑 이벤트

Fig. 6 Diverging fadeout bubble popping event 
그림 7은 버블포핑 시스템의 초기 구조를 보여준다. 사용 자는 오른손에 진동촉각마우스를 잡고 있다. 노란색 작은 볼은 진동촉각마우스의 그래픽 마우스이고, 녹색 및 파란 색의 볼은 버블들이다. 모니터에는 웹캠이 부착되어 있고, 책상위에 있는 마커 패턴을 인식하여, ARtoolkit에서 카메 라와 마커 패턴의 상대적 카메라 파라메터를 알려준다.
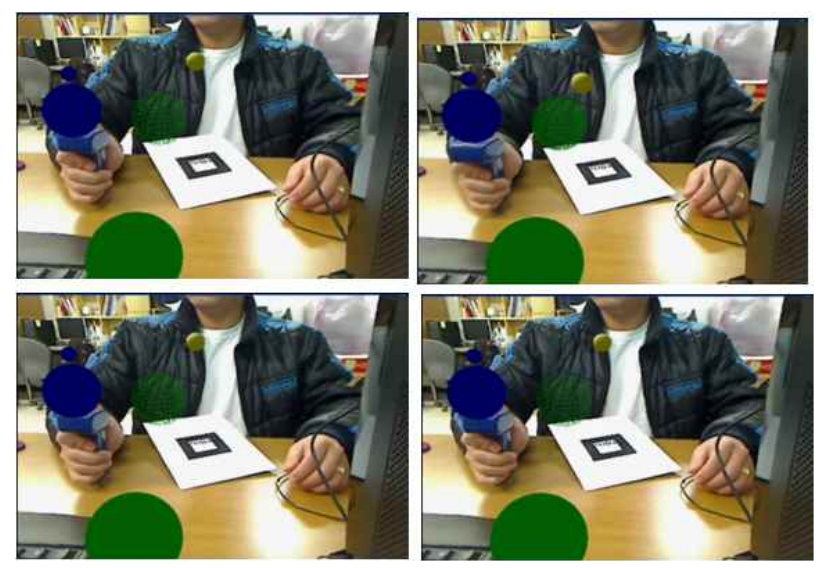

그림 7. 버블 포핑 시스템의 초기 화면

Fig. 7 The initial setup of bubble popping system

진동촉각마우스을 이동하면, 이에 따라 그래픽 마우스도 이동하게 된다. 그래픽 마우스가 버블과 충돌하면, 버블 포 핑 이벤트가 발생하는데, 이 페이드 아웃 이벤트는 그림
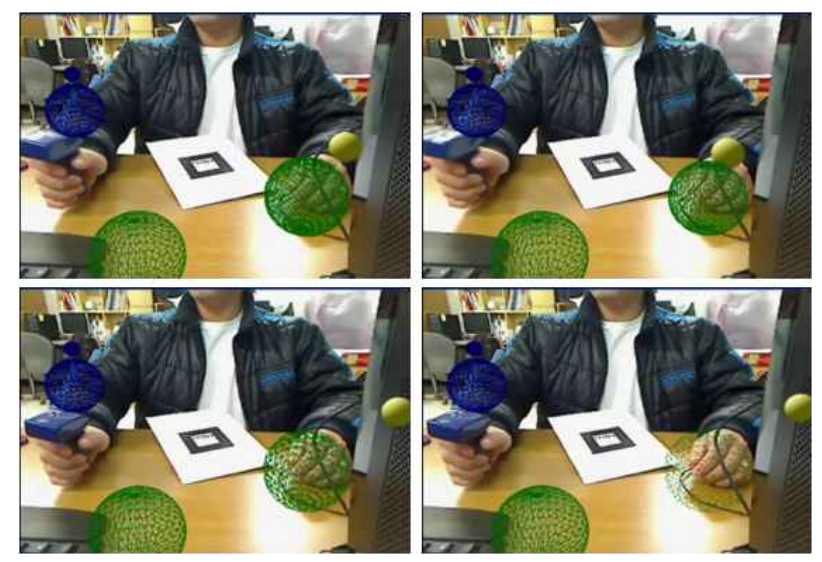

그림 8. 페이드 아웃 버블 포핑 이벤트

Fig. 8. shows a fade-out bubble popping event
8에서 보여준다. 버블의 삼각형 메쉬의 개수가 점진적으로 줄어들고, 최종적으로는 버블이 사라지게 된다.

그림 9는 발산 페이드 아웃을 보여준다. 노란색의 그래픽 볼은 사용자의 진동촉각마우스로 제어된다. 마우스가 녹색 의 버블 객체와 충돌하면, 버블 구의 중심으로부터 법선벡 터 방향으로 버블의 삼각형 메쉬는 점진적으로 이동하면서 점차적으로 사라지게 된다.
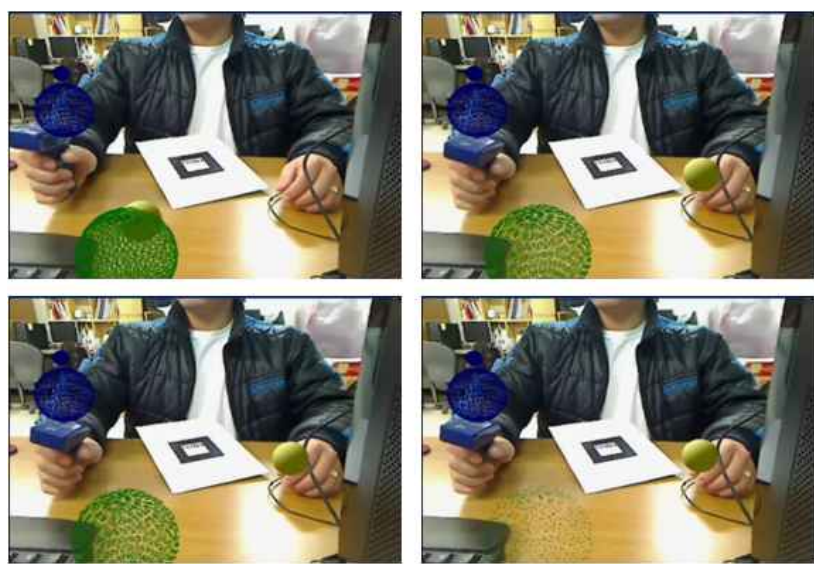

그림 9. 발산 페이드 아웃 버블 포핑 이벤트의 예

Fig. 9 An example of diverging fade-out bubble popping event

제안하는 증강현실 시스템이 사용자에게 전달하는 증감 을 분석하기 위해서 두가지의 주관평가 실험을 실행하였다. 실험 I 에서는 진동촉각을 ON/OFF하고, 동일 버블포핑 이 벤트를 보여주면서 진동촉각 증감도를 조사하였다. 실험 II 에서는 진동촉각을 $\mathrm{ON}$ 하고, 두가지의 버블포핑 이벤트를 보여주고 시각적 피드백을 평가하였다. 실험에서 각 실험 자는 각각 5 분 동안 주어진 환경에서 증강현실 시스템을 작동하도록 하였다. 증감도는 다음의 1 5의 값에서 주관적 으로 평가하였다: 전혀 증감이 없음 (1점), 증감이 조금 있 음 (2점), 증감향상이 중간정도임 (3점), 증감향상이 좋음 (4점), 증감향상이 매우 좋음 (5점).

주관평가의 결과는 그림 10 및 11 에서 보여진다. 실험자 들의 평균 증감도를 평가한 결과, 마우스 진동을 미사용했 을 때에 (진동촉각 off) 2.6 스케일을 얻었고, 진동촉각 on 에서는 4.0 의 평가치를 얻었다. 이 실험에서는 1.4 스케일 
의 증감향상이 있었다. 실험 II에서는 발산페이드아웃 기법 이 페이드아웃 기법보다 0.4 스케일의 증감향상이 있었다. 평가실험에서 진동촉각이 시각적 효과보다 더 우수한 증감 을 전달하는 것을 검증하였다. 또한 실험 I 에서의 증가율이 실험 II보다 높은 것은 진동촉각이 시각적 피드백보다 증감 효과에 더 큰 영향을 준다는 것이다.

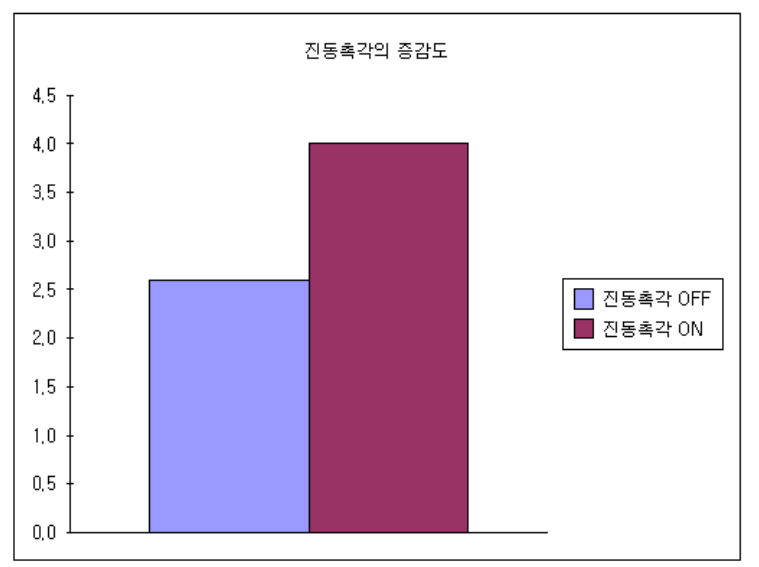

그림 10. 진동촉각센싱을 on/off 상태에서 사용자가 느끼는 평균 증감도의 측정 결과

Fig. 10. Evaluation result of the degree of average augmented reality at vibro-tactile sensing on/off

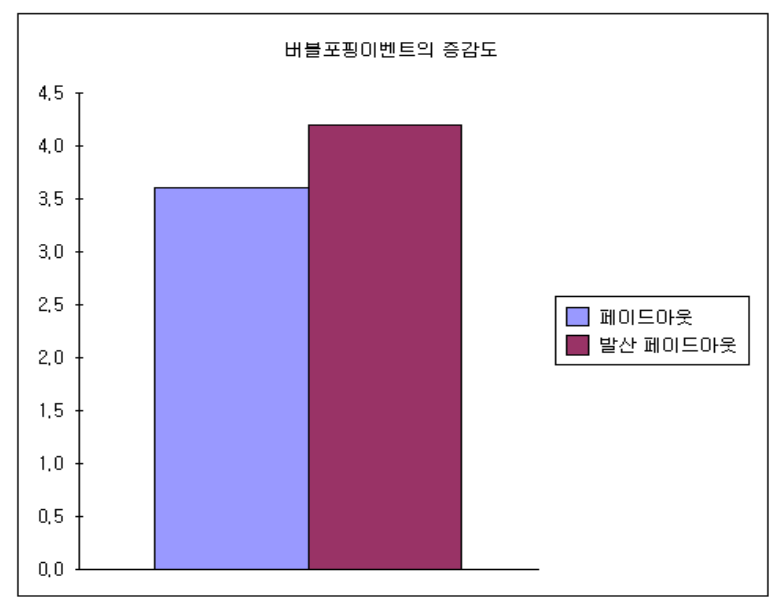

그림 11. 진동촉각센싱을 on한 상태에서 버블포핑 이벤트의 평균 증감도 Fig. 10. Evaluation result of the degree of average augmented reality for bubble popping event. The vibro-tactile sensing is on.

\section{VI. 결 론}

본 논문에서는 진동촉각마우스를 활용하는 버블포핑 증 강현실 시스템을 제안하였다. 사용자와 인터랙션으로 버블 의 이동과 포핑 기법을 활용하는 콘텐츠로써 향후 많은 발 전이 기대되는 증강현실 시스템이다. 이 콘텐츠는 엔터테 인먼트 및 교육용으로 활용이 가능하다. 버블 이벤트로써 버블이 마우스와 충돌 시 점진적으로 사라지고, 또한 발산 하면서 사라지는 두가지의 버블 포핑 알고리즘을 제안하였 다. 여기에 진동촉각마우스와 결합하여 보다 능동적이고 실감나는 증강현실 시스템을 구현하였다. 기존의 시스템에 햅틱기기를 접목함으로써, 기존 방식보다 사용자에게 증감 의 제공이 가능하다. 주관 평가 실험에서는 진동촉각이 시 각적 피드백보다 더 우수한 증감을 전달하는 것을 검증하 였는데, 향후 증강현실에서 다양한 햅틱 기기의 적극적인 활용이 요구된다.

\section{참 고 문 헌}

[1] K. Moustakas, et. al, "A geometry education haptic VR application based on a new virtual hand representation", Proc. of IEEE Virtual Reality, 2005.

[2] L. Paolis and M. Pulimeno, "A simulation of a billiard game based on a marker detection", IEEE 2009.

[3] F. Liarokapis, M. White, P. Lister, "Augmented reality interface toolkit", Proc. of the Eighth International Conference on Information Visualization, 2004.

[4] C. Kirner, et. al, "Case studies on the development of games using augmented reality", IEEE International Conference on Systems, Man, and Cybernetics, Oct. 8-11, 2006.

[5] 이준훈, 하태진, 류제하, 우운택, “디지로그 북 저작을 위한 펜형 햅틱 사용 자 인터페이스의 개발", $\mathrm{HCI}$ 학술대회, 2009.

[6] C. E. Hughes, C. B. Stapleton, D. E. Hughes and E. M. Smith, "Mixed reality in education, entertainment, and training," IEEE Computer Graphics and Applications, Nov/Dec. 2005.

[7] G. Szibig, B. Solvang, C. Kiss, and P. Korondi, "Vibro-tactile feedback for VR systems," IEEE 2nd Conference Human system interface, May 2009.

[8] W. Piekarski and R. Smooth, "Robust gloves for 3D interaction in mobile outdoor AR environments," IEEE/ACM International Conference on Mixed and Augmented Reality, ISMAR 2006.

[9] I. Herst and J. Stark, "Comparing force magnitudes by means of vibro-tactile, auditory, and visual feedback," IEEE Int. Workshop on 
Haptic Audio, Visual Environments and their Applications, Oct. 2005.

[10] J. R. Vallino and C. M. Brown, "Haptics in Augmented Reality," Proc. IEEE Int'l Conf. Multimedia Computing and Systems (ICMCS '99), vol. 1, pp. 195-200, 1999

[11] http://www.hitl.washington.edu/artoolkit/documentation/, 2010년 6월.

[12] Ho-joong Yong, Jongwon Back, and Tae-Jeong Jang, "Stereo vision based human computer interaction with tactile stimulation," ETRI journal vol.29, no.3, pp.305-310, June 2007.

[13] P. Jiménez, F. Thomas and C. Torras, "3D collision detection: a survey," Computers \& Graphics, Vol. 25, Issue 2, Apr. 2001, pp. 269-285.

[14] F. S. Hill, Jr, Computer graphics using OpenGL, 2nd Ed. Prentice-Hall, 1990.

저 자 소 개

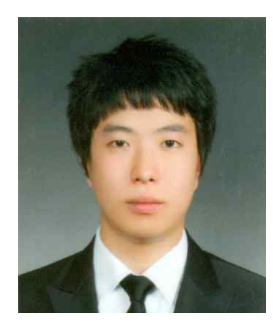

\section{정 다 운}

- 2009년 8월 : 강원대학교 컴퓨터정보통신공학과 학사

- 2009년 9월 현재 : 강원대학교 컴퓨터정보통신공학과 석사과정

- 주관심분야 : $3 \mathrm{D}$ 입체영상처리, 증강현실

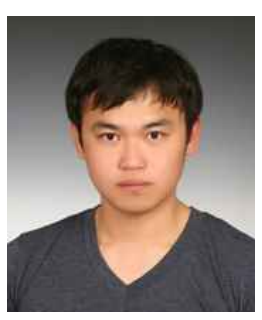

이 우 근

- 2011년 2월 : 강원대학교 컴퓨터정보통신공학과 학사

- 주관심분야 : 증강현실, 의료영상처리

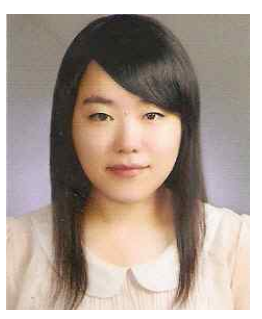

\section{장 성 은}

- 2010년 8월 : 강원대학교 컴퓨터정보통신공학과 학사

- 2010년 9월 현재 : 강원대학교 컴퓨터정보통신공학과 석사과정

- 주관심분야 : 의료영상처리, 증강현실, $3 \mathrm{D}$ 모바일통신

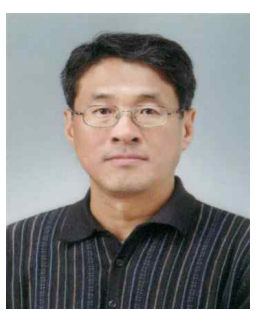

\section{김 만 배}

- 1983년 : 한양대학교 전자공학과 학사

- 1986년 : University of Washington 전기공학과 공학석사

- 1992년 : University of Washington 전기공학과 공학박사

- 1992년 1998년 : 삼성종합기술원 수석연구원

- 1998년 현재 : 강원대학교 컴퓨터정보통신공학과 교수

- 주관심분야 : $3 \mathrm{D}$ 영상처리 입체변환, 의료융합, 증강현실 